\title{
Effects of ASM-024, a modulator of acetylcholine receptor function, on airway responsiveness and allergen-induced responses in patients with mild asthma
}

\author{
Louis-Philippe Boulet MD FRCPC ${ }^{1}$, Gail M Gauvreau PhD², Donald W Cockcroft MD FRCPC FAAAAI ${ }^{3}$, \\ Beth Davis $\mathrm{PhD}^{3}$, Luc Vachon $\mathrm{PhD}^{4}$, Yvon Cormier $\mathrm{MD}^{1,4}$, Paul M O'Byrne MB FRCPC ${ }^{2}$
}

\begin{abstract}
L-P Boulet, GM Gauvreau, DW Cockcroft, et al. Effects of ASM024, a modulator of acetylcholine receptor function, on airway responsiveness and allergen-induced responses in patients with mild asthma. Can Respir J 2015;22(4):230-234.
\end{abstract}

OBJECTIVES: To evaluate the safety, tolerability and clinical activity of ASM-024, a new cholinergic compound with dual nicotinic and muscarinic activity, in mild allergic asthma.

METHODS: The present study involved 24 stable, mild allergic asthmatic subjects. In a cross-over design, ASM-024 (50 mg or $200 \mathrm{mg}$ ) or placebo were administered once daily by nebulization over three periods of nine consecutive days separated by a three-week washout. The effect of each treatment on the forced expiratory volume in $1 \mathrm{~s}\left(\mathrm{FEV}_{1}\right)$, provocative concentration of methacholine causing a $20 \%$ decline in $\mathrm{FEV}_{1}\left(\mathrm{PC}_{20}\right)$, early and late asthmatic responses, and allergen-induced inflammation were measured.

RESULTS: Seventeen subjects completed the study. During treatment with ASM-024 at $50 \mathrm{mg}$ or $200 \mathrm{mg}$, the $\mathrm{PC}_{20}$ value increased respectively from a mean $( \pm \mathrm{SD}) 2.56 \pm 3.86 \mathrm{mg} / \mathrm{mL}$ to $4.11 \mathrm{mg} / \mathrm{mL}(\mathrm{P}=0.007)$, and from $3.12 \pm 4.37 \mathrm{mg} / \mathrm{mL}$ to $5.23 \mathrm{mg} / \mathrm{mL}(\mathrm{P}=0.005)$ (no change with placebo). On day 7 (day preceding allergen challenge), postdosing $\mathrm{FEV}_{1}$ increased by $2.0 \%$ with $50 \mathrm{mg}(\mathrm{P}=0.005)$ and $1.9 \%$ with $200 \mathrm{mg}(\mathrm{P}=0.008)$ (placebo $-1.1 \%)$. ASM-24 had no inhibitory effect on early and late asthmatic responses, nor on sputum eosinophil or neutrophil levels. ASM-024 induced no serious adverse events, but caused cough in $22 \%$ and $48 \%$ of the subjects with $50 \mathrm{mg}$ and $200 \mathrm{mg}$, respectively, compared with $10 \%$ who were on placebo.

CONCLUSIONS: ASM-024 did not inhibit allergen-induced asthmatic response and related airway inflammation, but reduced methacholine airway responsiveness and slightly improved lung function. The mechanism by which ASM-024 improves these outcomes requires further study.

Key Words: Allergen challenge; Asthma; Nicotinic receptor agonists

$\mathrm{T}$ he main goal of asthma management is to achieve adequate control of the disease, mainly in reducing the underlying airway inflammatory process and airway hyper-responsiveness (1). Inhaled corticosteroids are pivotal drugs to reduce underlying asthmatic airway inflammation, although they may not be sufficient to control asthma in a significant proportion of subjects $(2,3)$. Asthma is an heterogeneous condition; it has recently been emphasized that it is expressed as a variety of phenotypes and endotypes (4). Therefore, the development of new agents acting on various components of the inflammatory cascade and mechanisms of bronchoconstriction are being investigated.

Acetylcholine $(\mathrm{ACH})$ is an endogenous neurotransmitter of the central and peripheral nervous systems, and a signalling mediator in many non-neuronal cells involved in the regulation of several physiological functions including immune regulation and bronchomotor tone. $\mathrm{ACH}$ receptors include nicotinic and muscarinic receptors, and are expressed on neuronal and muscle cells, and also on inflammatory and structural cells in the respiratory tract (5). Nicotinic ACH receptors
Les effets de l'ASM-024, un modulateur de la fonction des récepteurs de l'acétylcholine, sur la réactivité des voies aériennes et les réponses induites par les allergènes chez les patients atteints d'un asthme bénin

OBJECTIFS : Évaluer l'innocuité, la tolérabilité et l'activité clinique de l'ASM-024, un nouveau composé cholinergique ayant une double activité nicotinique et muscarinique en cas d'asthme allergique bénin.

MÉTHODOLOGIE : La présente étude portait sur 24 sujets atteints d'asthme allergique bénin stabilisé. Dans une étude transversale, une nébulisation d'l'ASM-024 (50 mg ou $200 \mathrm{mg}$ ) ou de placebo a été administrée une fois par jour pendant trois périodes de neuf jours consécutifs, entrecoupées d'une période de lessivage de trois semaines. Les chercheurs ont mesuré l'effet de chaque traitement sur le volume expiratoire maximal par seconde (VEMS), la concentration provocatrice de méthacholine responsable d'une diminution de $20 \%$ de la VEMS $\left(\mathrm{CP}_{20}\right)$, les réponses asthmatiques précoces et tardives et l'inflammation induite par les allergènes.

RÉSULTATS : Dix-sept sujets ont terminé l'étude. Pendant le traitement de $50 \mathrm{mg}$ ou de $200 \mathrm{mg}$ d'ASM-024, la valeur $\mathrm{CP}_{20}$ s'est accrue respectivement d'une moyenne ( \pm ÉT) de $2,56 \pm 3,86 \mathrm{mg} / \mathrm{mL}$ à $4,11 \mathrm{mg} / \mathrm{mL}(\mathrm{P}=0,007)$ et de $3,12 \pm 4,37 \mathrm{mg} / \mathrm{mL}$ à $5,23 \mathrm{mg} / \mathrm{mL}(\mathrm{P}=0,005)$ (aucun changement par rapport à un placebo). Le jour 7 (la veille d'une épreuve aux allergènes), la VEMS après la dose a augmenté de $2,0 \%$ grâce à 50 mg d'ASM-24 $(\mathrm{P}=0,005)$ et de $1,9 \%$ grâce à 200 mg d'ASM-24 ( $\mathrm{P}=0,008)$ (placebo $-1,1 \%)$. L'ASM-24 n'avait pas d'effet inhibiteur sur la réaction asthmatique précoce et tardive, ni sur les taux d'éosinophiles ou de neutrophiles dans les expectorations. L'ASM-024 n'a induit aucun effet secondaire grave, mais a provoqué une toux chez $22 \%$ et $48 \%$ des sujets avec la dose de $50 \mathrm{mg}$ et de $200 \mathrm{mg}$, respectivement, par rapport à $10 \%$ de ceux qui prenaient un placebo.

CONCLUSIONS : L'ASM-024 n'inhibait pas la réponse asthmatique induite par les allergènes et l'inflammation connexe des voies aériennes, mais réduisait la réactivité de la méthacholine des voies aériennes et améliorait légèrement la fonction pulmonaire. Le mécanisme par lequel l'ASM-024 améliore ces résultats mérite des études plus approfondies.

(nAChR) are ionotropic receptors; however, their activation can induce anti-inflammatory effects via signal transduction pathways primarily through interaction with the $\alpha 7$ receptor (6) and also with other nicotinic receptor subtypes $(7,8)$. nAChR may also be involved in airway smooth muscle relaxation (9), while muscarinic receptors are metabotropic receptors involved in airway smooth muscle contraction. Therefore, modulation of $\mathrm{ACH}$ receptor function may provide another target for the treatment of airway diseases.

ASM-024 (di-ethyl-4-phenylhomopiperazinium) is a small synthetic compound developed for airway inflammatory diseases as the primary target therapeutic indication. It acts as a dual anti-inflammatory and bronchodilating agent in preclinical models (10). Although mechanism of action of ASM-024 is still being investigated, observations from whole-cell voltage-clamp experiments have revealed effects on both nicotinic and muscarinic receptors. ASM-024 alone did not induce activation of any of the nAChR subtypes tested (unpublished data obtained from collaboration with Dr Ken Kellar [Georgetown University, Washington DC] and Dr Roger L Papke [University of

${ }^{1}$ Institut universitaire de cardiologie et de pneumologie de Québec, Laval University, Quebec, Quebec; ${ }^{2}$ McMaster University, Hamilton,Ontario;

${ }^{3}$ University of Saskatchewan, Saskatoon, Saskatchewan; ${ }^{4}$ Asmacure Ltée, Quebec

Correspondence: Dr Louis-Philippe Boulet, Institut universitaire de cardiologie et de pneumologie de Québec, 2725 Chemin Sainte-Foy, Québec,

Québec G1V 4G5. Telephone 418-656-4747, fax 418-656-4762, e-mail lpboulet@med.ulaval.ca 
Florida, Florida, USA]) but rather blocks the activation of the $\alpha 3 \beta 4$ and $\alpha 7$ nicotinic receptor ion channel function by $\mathrm{ACH}$ or nicotine.

ASM-024 is, however, able to activate the $\alpha 7 \mathrm{nAChR}$ channel opening in the presence of the positive allosteric modulator (PNU. 120596), indicating that ASM-024 behaves as a 'silent agonist' that places the receptor in a desensitized state. Compounds with similar properties have been shown to induce signal transduction pathways independently of ion channel activation (11). Moreover, ASM-024 has demonstrated an antagonist effect on $\mathrm{ACH}$-evoked activation at the M1, M2 and M3 muscarinic receptors expressed in Xenopus oocytes (12). It has shown a very good safety profile when administered by inhalation to healthy volunteers, the principal effects being local irritation and cough, mainly at high doses (13).

The primary objective of the present study was to evaluate the potential inhibitory effects of ASM-024 on airway responsiveness, airflow limitation and allergen-induced asthmatic responses in mild steroid-naive asthmatic subjects. We also obtained preliminary information regarding the dose-response profile of ASM-024 in terms of safety, tolerability and pharmacokinetic profile in this subject population.

\section{Subjects}

\section{METHODS}

The present study involved 24 stable, steroid-naive, mild allergic nonsmoking asthmatic subjects with previously documented allergeninduced early and late asthmatic responses, respectively defined as an acute fall in forced expiratory volume in $1 \mathrm{~s}\left(\mathrm{FEV}_{1}\right) \geq 20 \%$ within $2 \mathrm{~h}$ following allergen challenge and a fall in $\mathrm{FEV}_{1} \geq 15 \%$ between $3 \mathrm{~h}$ and $7 \mathrm{~h}$ following allergen challenge.

Subjects included men and women $\geq 18$ and $\leq 50$ years of age with mild allergic asthma using inhaled short-acting beta 2 -agonists on demand as the only asthma medication. Female subjects of childbearing potential were required to use adequate contraception. All subjects were required to have an $\mathrm{FEV}_{1} \geq 70 \%$ of predicted, a body mass index $\geq 19 \mathrm{~kg} / \mathrm{m}^{2}$ and $\leq 35 \mathrm{~kg} / \mathrm{m}^{2}$, and a baseline methacholine provocation concentration inducing a $20 \%$ fall in $\mathrm{FEV}_{1}\left(\mathrm{PC}_{20}\right)<16 \mathrm{mg} / \mathrm{mL}$.

Subjects could not be enrolled in the study if they had clinically significant conditions or illnesses other than mild allergic asthma or systemic diseases that placed subjects at risk as a result of their participation in the study, influence the results or outcome of the study, or had an impact on the subjects' ability to participate in the study. They should not have had a respiratory tract infection or worsening of asthma within 14 days before baseline and no significant abnormal results on baseline screening including blood tests and electrocardiogram. Beta 2 -agonists and caffeinated beverages were withheld for at least $8 \mathrm{~h}$ before laboratory visits.

\section{Study design}

The present analysis was a three-centre, randomized, cross-over, doubleblind, placebo-controlled study of ASM-024 administered as once-daily dosing (Figure 1). The study was divided into three parts: screening (part 1); baseline (part 2); and pretreatment/treatment (part 3). In part 1 , subjects were screened to document early and late asthmatic responses to allergen challenge, and perform measurements of airway responsiveness to methacholine and induced sputum analysis. Then, at baseline, if the subjects continued to meet the eligibility criteria pretreatment, they were randomly assigned into the double-blinded treatment phase (part 3) of the study during which they received either ASM-024 (50 mg or $200 \mathrm{mg}$ ) or placebo, administered once daily by nebulization over three periods of nine consecutive days, each period separated by a three-week washout period. Following completion of the treatment phase, subjects were evaluated for an additional 14 days in a follow-up phase.

All subjects and trial staff were blinded to the random order until the database was locked. The study was approved by the ethics research committees of the participating institutions, and informed written consent was obtained from subjects.

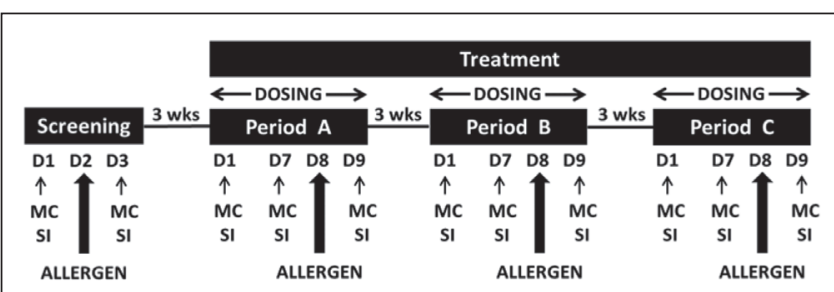

Legend: $D=$ day, $M C=$ methacholine challenge, $S \mathrm{~S}=$ sputum induction, $w \mathrm{ks}=$ weeks

Figure 1) Study design. The present analysis was a double-blinded, threeway crossover study of ASM-024 administered as once-daily doses by nebulization. Randomized evaluation of two doses of ASM-024 (50 mg and $200 \mathrm{mg}$ ) and placebo were performed in three different periods (nine consecutive days of dosing) separated by a three-week washout period

\section{Evaluation and laboratory procedures}

Study medication: The study medication was supplied as $5 \mathrm{~mL}$ vials containing an isotonic saline solution for the placebo as well as for the doses of $50 \mathrm{mg}(12.5 \mathrm{mg} / \mathrm{mL})$ and $200 \mathrm{mg}(50 \mathrm{mg} / \mathrm{mL})$ of ASM-024. Doses were administered by nebulization over a period of $15 \mathrm{~min}$.

Methacholine challenges: Methacholine inhalation challenge was performed as described by Cockcroft et al (14), using tidal breathing, the aerosol being produced by a calibrated Wright nebulizer. The test was ended when a fall in $\mathrm{FEV}_{1}$ of at least $20 \%$ of the baseline value was recorded, after which the methacholine $\mathrm{PC}_{20}$ was calculated.

Allergen bronchoprovocation: Allergen challenges were performed as described by Boulet et al (15). The concentration of allergen extract required for inhalation was determined from a formula described by Cockcroft et al (16).

During the screening period, doubling concentrations of allergen were given until a $\geq 20 \%$ fall in $\mathrm{FEV}_{1}$ was achieved 10 min post allergen. The $\mathrm{FEV}_{1}$ was then measured at regular intervals up to $7 \mathrm{~h}$ after the last allergen inhalation. The same dose of allergen had to be administered on subsequent visits unless there was a safety issue, in which case the investigator could give a lower dose.

Sputum analysis: Sputum was induced and processed using the method described by Pizzichini et al (17). The total cell count was determined in blinded conditions using a Neubauer hemacytometer chamber (Hausser Scientific, USA) and expressed as the number of cells per millilitre of sputum. Cells were prepared on glass slides for differential counts and stained with Diff Quik (American Scientific Products, USA). One of the investigative sites was designated to perform centralized inflammatory cell counting for all of the sites. All sputum samples were used regardless of squamous cell contamination; however, the cell percentage was based only on the inflammatory cells and airway epithelial cells.

Blood analyses: On both day 1 and day 9 of each of the three treatment periods, blood samples were collected before the administration of the study medication and as soon as possible following the end of the inhalation period. The measurement of ASM-024 was performed in plasma using a validated good laboratory practice liquid chromatography/mass spectrometry method.

Sample size evaluation and statistical analysis: The per-protocol data were analyzed using the crossover design. Data were analyzed as mean \pm standard error of the mean (SEM) unless otherwise noted. Methacholine $\mathrm{PC}_{20}$ and sputum cell numbers were log-transformed before analyses. The ANCOVA method was used to evaluate the effects of treatment and period, controlling for possible carry over effects and followed with post hoc tests as applicable and appropriate.

\section{RESULTS}

Seventeen subjects completed the study per protocol. Seven subjects had to be withdrawn from the study due to study medication-induced cough $(n=2)$, respiratory infection $(n=1)$, asthma exacerbation $(n=2)$, prestudy condition $(n=1)$ and unrelated personal reason $(n=1)$. 


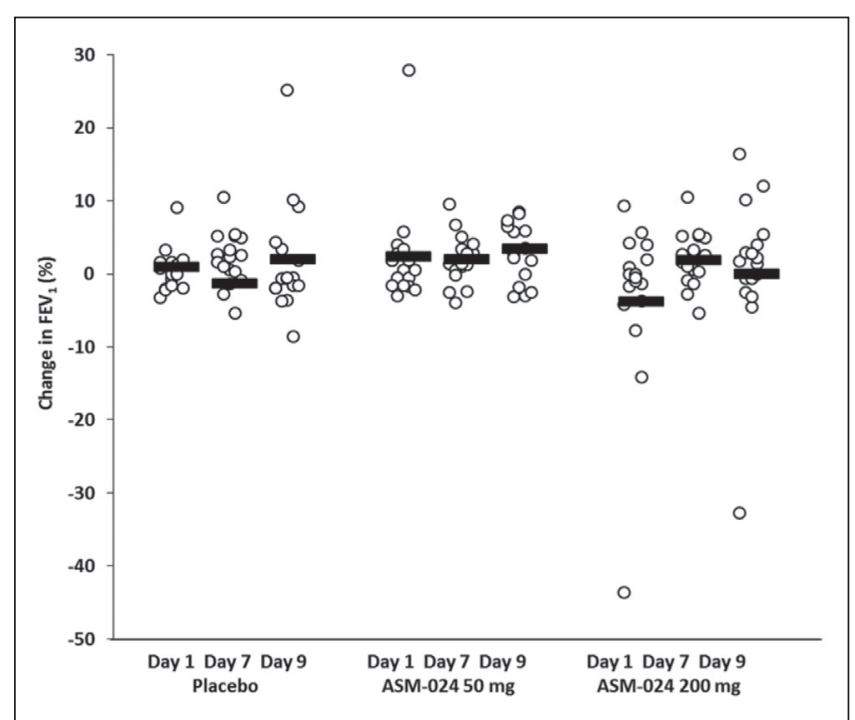

Figure 2) Baseline airway calibre: changes in forced expiratory volume in $1 \mathrm{~s}$ $\left(F_{1}\right)$ following inhalation of ASM-024. Data are expressed as the individual (circles) and mean (black bars) percent change observed immediately following the administration of the study medication on days 1, 7 and 9 for each treatment period (pairwise comparisons using ANOVA with, as factors, treatment, period, sequence, subject within sequence and carry-over)

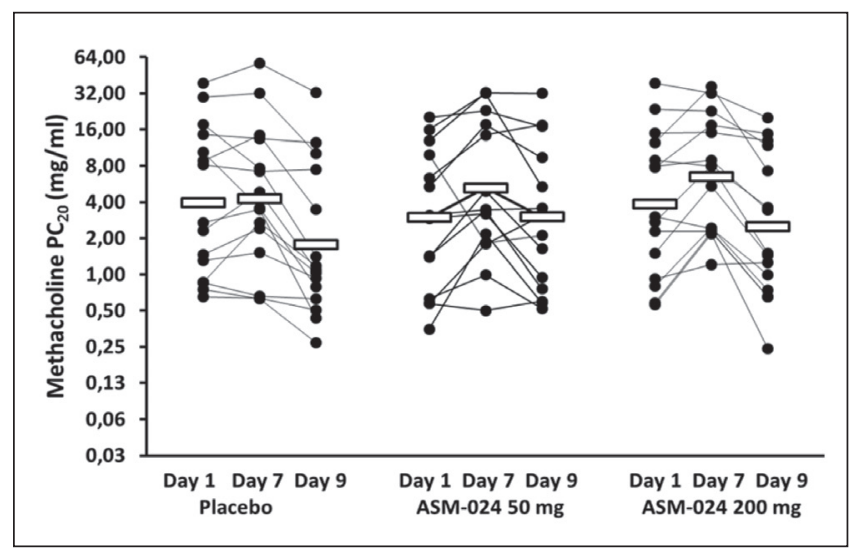

Figure 3) Airway responsiveness: influence of treatments on percent change in methacholine provocation concentration inducing a 20\% fall in forced expiratory volume in $1 \mathrm{~s}\left(\mathrm{PC}_{20}\right)$ after allergen challenge. Data expressed as individual (circles) and geometric mean (open bars) $\mathrm{PC}_{20}$ observed on day 1 ('pre-treatment') and day 7 ('post-treatment') and day 9 ('postallergen challenge'). Repeated measures two-way ANOVA for treatment and time were followed by post hoc tests

Baseline airway calibre and airway responsiveness

On day 7, there was a slight but statistically significant increase in $\mathrm{FEV}_{1}$ of $2.0 \%$ following the administration of $50 \mathrm{mg}$ of ASM-024 (P=0.005 versus placebo) and of $1.9 \%$ with the $200 \mathrm{mg}$ dose $(\mathrm{P}=0.008)$, while with placebo the change was $-1.1 \%$ (Figure 2 ). The $\mathrm{FEV}_{1} /$ forced vital capacity ratio displayed a similar magnitude of change on day $7(\mathrm{P}<0.05$ [data not shown]). Such effects were not observed on the first day of treatment or on day 9 (ie, following the last allergen challenge).

There was a significant improvement in methacholine $\mathrm{PC}_{20}$ on day 7 of treatment, before the allergen challenge on day 8 , with both doses of ASM-024 (Figure 3). The mean $\mathrm{PC}_{20}$ value was $3.97 \mathrm{mg} / \mathrm{mL}$ (range 0.66 to $39.0 \mathrm{mg} / \mathrm{mL}$ ) before and $4.29 \mathrm{mg} / \mathrm{mL}$ (range 0.63 to $57.0 \mathrm{mg} / \mathrm{mL}$ ) after placebo period ( $\mathrm{P}=0.98)$. During treatment with ASM-024 $50 \mathrm{mg}$, $\mathrm{PC}_{20}$ increased from $2.98 \mathrm{mg} / \mathrm{mL}$ (range 0.35 to $20.16 \mathrm{mg} / \mathrm{mL}$ ) to $5.24 \mathrm{mg} / \mathrm{mL}$ (range 0.5 to $32.4 \mathrm{mg} / \mathrm{mL})(\mathrm{P}=0.006)$ and during

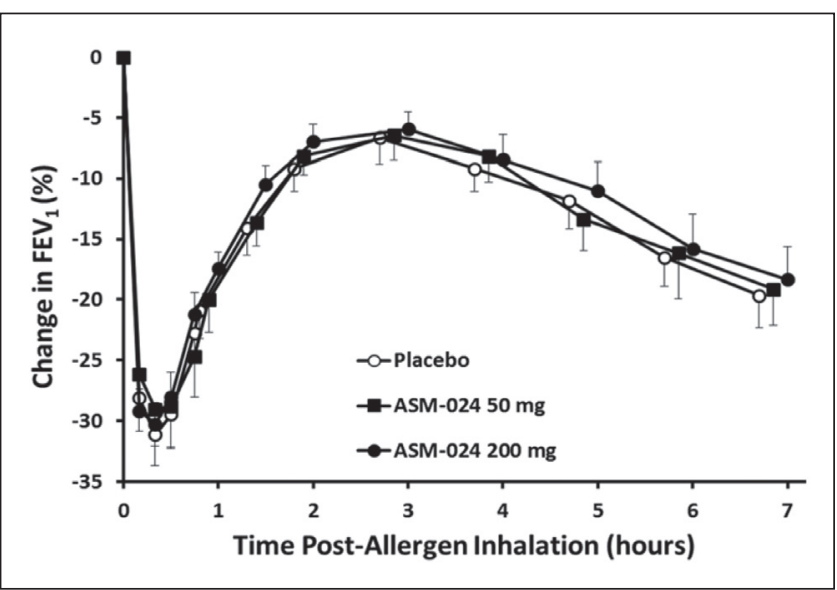

Figure 4) Allergen challenges: influence of treatments on the percent fall in forced expiratory volume in $1 \mathrm{~s}\left(\mathrm{FEV}_{1}\right)$ after allergen challenge. No significant inhibitory effect was observed after ASM-024 compared with placebo

\section{TABLE 1}

Most frequently reported adverse events

\begin{tabular}{lccc}
\hline Adverse event & Placebo & ASM-024 (50 $\mathbf{~ g )}$ & ASM-024 (200 $\mathbf{~ g ) ~}$ \\
\hline Taste & $1(5)$ & $14(78)$ & $16(70)$ \\
Cough & $2(10)$ & $4(22)$ & $11(48)$ \\
Chest discomfort & None & $5(28)$ & $3(13)$ \\
Oropharyngeal pain & $2(10)$ & $1(6)$ & $3(13)$ \\
Headache & $1(5)$ & $3(17)$ & $1(4)$ \\
Throat tightness & $0(0)$ & $3(17)$ & $1(4)$ \\
Bronchospasm & None & $1(6)$ & $2(9)$ \\
Nausea & None & None & $3(13)$ \\
Upper aiway secretion & None & $1(6)$ & $1(4)$ \\
Wheezing & None & $0(0)$ & $2(9)$ \\
\hline
\end{tabular}

Data presented as $n(\%)$ unless otherwise indicated

treatment with $200 \mathrm{mg}$ from $3.87 \mathrm{mg} / \mathrm{mL}$ (range 0.56 to $38.85 \mathrm{mg} / \mathrm{mL}$ ) to $6.55 \mathrm{mg} / \mathrm{mL}$ (range 1.21 to $36.33 \mathrm{mg} / \mathrm{mL})(\mathrm{P}=0.003)$.

\section{Allergen challenges}

ASM-24 had no inhibitory effect on the allergen-induced change in methacholine $\mathrm{PC}_{20}$, or early and late asthmatic responses (Figures 3 and 4).

\section{Airway inflammation}

ASM-024 had no significant effect on the mean numbers of induced sputum total cell, eosinophil or neutrophil counts (or percentages) following the allergen challenge. No changes in white blood cell counts were observed following treatment. At the end of the treatment period, a statistically significant decrease in the blood lymphocyte count was observed for the dose of $50 \mathrm{mg}$ compared with the placebo $(\mathrm{P}=0.009)$, with a similar trend observed for the dose of $200 \mathrm{mg}(\mathrm{P}=0.09)$.

\section{Side effects}

ASM-024 induced no serious adverse events but coughing was reported in $22 \%$ and $48 \%$ of the subjects at the doses of $50 \mathrm{mg}$ and $200 \mathrm{mg}$, respectively, as compared with $10 \%$ on placebo, and bad taste was reported in $78 \%$ and $70 \%$ of the subjects at the doses of $50 \mathrm{mg}$ and $200 \mathrm{mg}$, respectively, compared with $5 \%$ on placebo (Table 1).

\section{Pharmacokinetics}

ASM-024 was detected in plasma in all subjects who received it at either $50 \mathrm{mg}$ or $200 \mathrm{mg}$. Individual postdosing plasma concentrations ranged between $0.7 \mathrm{ng} / \mathrm{mL}$ and $79 \mathrm{ng} / \mathrm{mL}$ at the $50 \mathrm{mg}$ dose, and between $1.9 \mathrm{ng} / \mathrm{mL}$ and $311 \mathrm{ng} / \mathrm{mL}$ at the $200 \mathrm{mg}$ dose. On the whole, systemic exposure appeared to be proportional between the two dose levels, with mean $( \pm S D)$ values of $19 \pm 18($ median $=16[n=20])$ on 
day 1 and $24 \pm 16($ median $=23[\mathrm{n}=17])$ on day 9 at the $50 \mathrm{mg}$ dose, and $88 \pm 88($ median $=52[\mathrm{n}=21])$ on day 1 and $87 \pm 89($ median $=44$ [n=18]) $\mathrm{ng} / \mathrm{mL}$ on day 9 at the $200 \mathrm{mg}$ dose. Residual levels of ASM024 were observed predosing in some subjects in the morning of day 9 following repeat administration at both doses of $50 \mathrm{mg}$ or $200 \mathrm{mg}$, with levels up to $4 \mathrm{ng} / \mathrm{mL}$ and $7 \mathrm{ng} / \mathrm{mL}$, respectively. On the whole, there was no evidence of a clear relationship between the individual extent of systemic exposure to ASM-024 and the parameters associated with safety or clinical activity.

\section{DISCUSSION}

The present study showed that although ASM-024 had no significant effect on allergen-induced allergic asthmatic responses and induced sputum cell differential, it decreased methacholine response over time.

ASM-024 development was based on the hypothesis of a role for the cholinergic system in the regulation of airway bronchomotor tone and inflammation. Recent studies have demonstrated that $\mathrm{ACH}$ is also synthesized by non-neuronal cells, including inflammatory and epithelial cells, and is involved in the regulation of inflammation through binding to nicotinic receptors and, in particular, with the $\alpha 7$ subunit ( $\alpha 7 \mathrm{nAChR}$ ), and also with other subtypes (18). Nicotine and other nicotinic receptor agonists have demonstrated similar antiinflammatory properties (19). However, the addictive properties of nicotine strongly limits its therapeutic potential. ASM-024 was developed to modulate the function of nAChRs, but without addictive properties. In the present study, we could not find significant effects of the drug on inflammatory features, except for a mild change in lymphocyte count of uncertain significance.

DMPP (1,1-dimethyl-4-phenyl piperazinium), a nicotinic receptor agonist that does not cross the blood brain barrier, was initially studied. It demonstrated both anti-inflammatory and smooth muscle relaxant properties (20-22). ASM-024, a quaternary ammonium compound and an analogue of DMPP, has anti-inflammatory, smooth muscle relaxant and bronchoprotective properties in various in vitro and in vivo models (23). ASM-024 was also shown to have a potential antimuscarinic effect. However, the precise mechanism of action of ASM024 remains to be further established.

The allergen bronchoprovocation model has been used to explore potential usefulness of anti-asthma agents (15). Drugs that inhibited late asthmatic allergic responses were universally effective in treating asthma, although the magnitude of this effect could not be predicted. We used this method to test ASM-024 but found no significant effect on induced sputum cellular airway inflammation, nor on allergeninduced asthmatic responses. However, we observed a significant effect of ASM-024 on methacholine responses and airway calibre, suggesting that it may have benefits in the treatment of asthma, particularly with regard to its bronchoprotective effects.

In standard radioligand receptor binding competition assays, ASM024 showed inhibition at the low micromolar range (half-maximal inhibitiry concentration $\left[\mathrm{IC}_{50}\right] 19 \mu \mathrm{M}$ and $\mathrm{a} \mathrm{K}_{\mathrm{i}} 13 \mu \mathrm{M}$ ) for nonselective $n A C h R$ subtypes, and low binding affinity for most of the $n A C h R$ subtypes tested, except for the human $\alpha 3 \beta 4$ receptor, for which $\mathrm{K}_{\mathrm{i}}$ was $0.88 \mu \mathrm{M}$. Recent observations from whole-cell voltage-clamp experiments on human $\alpha 3 \beta 4$ and $\alpha 7$ nicotinic receptor subtypes expressed in Xenopus oocytes have revealed that ASM-024 does not activate the ion channel opening when used alone, but inhibits ACH-evoked responses, indicating an antagonist effect on ion channel activation. However, when co-applied with the type II $\alpha 7$ positive allosteric modulator, PNU-120596, which elicits a conformational change of the receptor, ASM-024 appears to function as an agonist and effectively activates the $\alpha 7$ ion channel (12). Compounds with similar properties are defined as 'silent agonists' that could mediate signal transduction pathways independantly of ion channel activation (11).

Similarly, receptor binding assays for the various muscarinic receptor subtypes indicated low binding affinity, but the capacity to decrease muscarinic responses to ACH of M1, M2 and M3 AChR expressed in Xenopus oocytes. These observations indicate a complex multifunctional mechanism of action, which remains under investigation. The bronchoprotective effect is, however, unlikely to be solely due to its influence on airway calibre because this last effect was small compared with the change in airway response.

Finally, with regard to airway responsiveness, some subjects had a $\mathrm{PC}_{20}$ methacholine $>16 \mathrm{mg} / \mathrm{mL}$. This can be explained by the fact that their study was performed outside their allergen season. All had previously been diagnosed as having mild allergic asthma.

With regard to side effects of the drug, the most commonly reported was a cough. Although uncertain, explanations for this may include the bitter taste of the compound, a local irritation by the formulation, with a relatively long duration of administration.

\section{CONCLUSION}

In a population of mild asthmatic subjects, ASM-024 did not inhibit allergen-induced asthmatic response and related airway inflammation, but significantly reduced methacholine airway responsiveness and slightly improved baseline lung function. The mechanism by which ASM-024 improves these outcomes requires further study. We believe this drug has sufficient therapeutic potential to warrant exploration of its effects in obstructive airways diseases.

FUNDING: This study was funded by Asmacure Ltée and the AllerGen Network of Centers of Excellence, Clinical Investigator Collaborative.

DISCLOSURES: LPB received grants from Asmacure Ltée to perform studies on ASM-024. YC is a cofounder of Asmacure Ltée which funded this research. He owns shares and is a part time employee of the Company. LV is a previous employee of Asmacure Ltée of which he owns stock options. He still provides remunerated consultant services to the Company. GGM, POB, DWC, BD and LV have no financial disclosures or conflicts of interest to declare.

\section{REFERENCES}

1. Holgate ST. Stratified approaches to the treatment of asthma. Br J Clin Pharmacol 2013;76:277-91.

2. Louis R, Schleich F, Barnes PJ. Corticosteroids: Still at the frontline in asthma treatment? Clin Chest Med 2012;33:531-41.

3. Bateman ED, Boushey HA, Bousquet J, et al. Can guideline-defined asthma control be achieved? The Gaining Optimal Asthma ControL study. Am J Respir Crit Care Med 2004;170:836-44.

4. Lotvall J, Akdis CA, Bacharier LB, et al. Asthma endotypes: A new approach to classification of disease entities within the asthma syndrome. J Allergy Clin Immunol 2011;127:355-60.

5. Arneric SP, Holladay M, Williams M. Neuronal nicotinic receptors: A perspective on two decades of drug discovery research. Biochem Pharmacol 2007;74:1092-101.

6. de Jonge WJ, van der Zanden EP, The FO, et al. Stimulation of the vagus nerve attenuates macrophage activation by activating the Jak2-STAT3 signaling pathway. Nature Immunol 2005;6:844-51.

7. Hosur V, Loring RH. Alpha4beta, nicotinic receptors partially mediate anti-inflammatory effects through Janus kinase 2-signal transducer and activator of transcription 3 but not calcium or cAMP signaling. Molecular Pharmacol 2011;79:167-74.

8. Simard AR, Gan Y, St-Pierre S, et al. Differential modulation of EAE by alpha $9 *$ - and beta2*-nicotinic acetylcholine receptors. Immunol Cell Biol 2013;91:195-200.

9. Blanchet MR, Israel-Assayag E, Cormier Y. Modulation of airway inflammation and resistance in mice by a nicotinic receptor agonist. Eur Respir J 2005;26:21-7.

10. Assayag EI, Beaulieu MJ, Cormier Y. Bronchodilatory and antiinflammatory effects of ASM-024, a nicotinic receptor ligand, developed for the treatment of asthma. PloS One 2014;9:e86091.

11. Chojnacka K PR, Horenstein NA Synthesis and evaluation of a conditionally-silent agonist for the $\alpha 7$ nicotinic acetylcholine receptor Bioorganic Medicin Chem Lett 2013;23:4145-9.

12. Stokes C, Israël-Assayag E, Papke RL. A minimal pharmacophore for a nicotinic alpha7 silent agonist,relevance for the therapeutic development of treatments for asthma. Presented at the Society for Neuroscience, San Diego, November 9 to 13, 2013. (Abst) 
13. Cormier Y, Furci PG, Israël-Assayag E, Vachon L. Characterization of the oharmacokinetic and safety profile of ASM-024, a novel niconitic agonist being developed for asthma, following inhalation in human subjects. Am J Respir Crit Care Med 2011;183:A4503.

14. Cockcroft DW. Airway responsiveness: Measurement and interpretation. In: Hargreave FE, Woolcock, AJ, ed. Measure of Airway Responsiveness to Inhaled Histamine or Methacholine; Method of Continuous Aerosol Generation and Tidal Breathing Inhalation. Mississauga: Astra Pharmaceuticals Canada Ltd, 1985:22-28.

15. Boulet LP, Gauvreau G, Boulay ME, O'Byrne P, Cockcroft DW. The allergen bronchoprovocation model: An important tool for the investigation of new asthma anti-inflammatory therapies. Allergy 2007;62:1101-10.

16. Cockcroft DW, Davis BE, Boulet LP, et al. The links between allergen skin test sensitivity, airway responsiveness and airway response to allergen. Allergy 2005;60:56-9.

17. Pizzichini E, Pizzichini MM, Efthimiadis A, et al. Indices of airway inflammation in induced sputum: Reproducibility and validity of cell and fluid-phase measurements. Am J Respir Crit Care Med $1996 ; 154: 308-17$
18. Tracey KJ, Czura CJ, Ivanova S. Mind over immunity. FASEB J 2001;15:1575-6.

19. Wang H, Yu M, Ochani M, et al. Nicotinic acetylcholine receptor alpha7 subunit is an essential regulator of inflammation. Nature 2003;421:384-8.

20. Dorion G, Israel-Assayag E, Beaulieu MJ, Cormier Y. Effect of 1,1-dimethylphenyl 1,4-piperazinium on mouse tracheal smooth muscle responsiveness. Am J Physiol Lung Cellular Molecular Physiol 2005;288:L1139-45.

21. Blanchet MR, Israel-Assayag E, Daleau P, Beaulieu MJ, Cormier Y. Dimethyphenylpiperazinium, a nicotinic receptor agonist, downregulates inflammation in monocytes/macrophages through PI3K and PLC chronic activation. Am J Physiol Lung Cellular Molecular Physiol 2006;291:L757-763.

22. Blanchet MR, Langlois A, Israel-Assayag E, et al. Modulation of eosinophil activation in vitro by a nicotinic receptor agonist. J Leukocyte Biol 2007;81:1245-51.

23. Israël-Assayag E, Beaulieu MJ, Vachon L, Cormier Y. Putative mechanisms of ASM-024-induced relaxation of isolated mouse tracheal preparation. Am J Respir Crit Care Med 2011;183:A1271. 


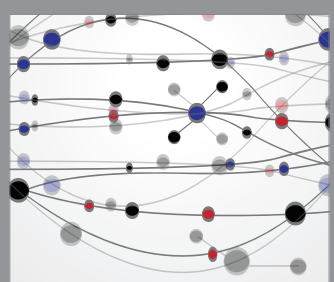

The Scientific World Journal
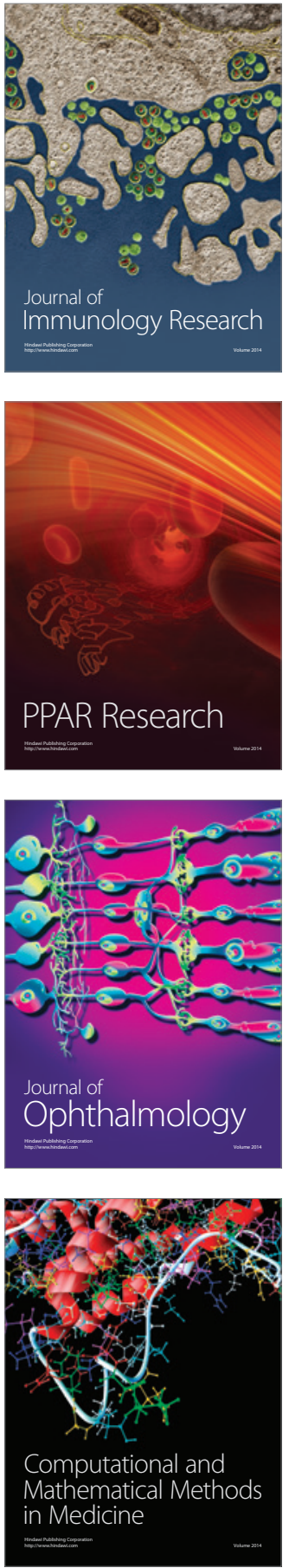

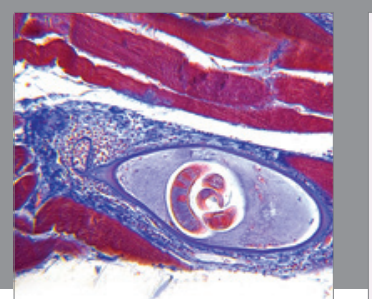

Gastroenterology Research and Practice

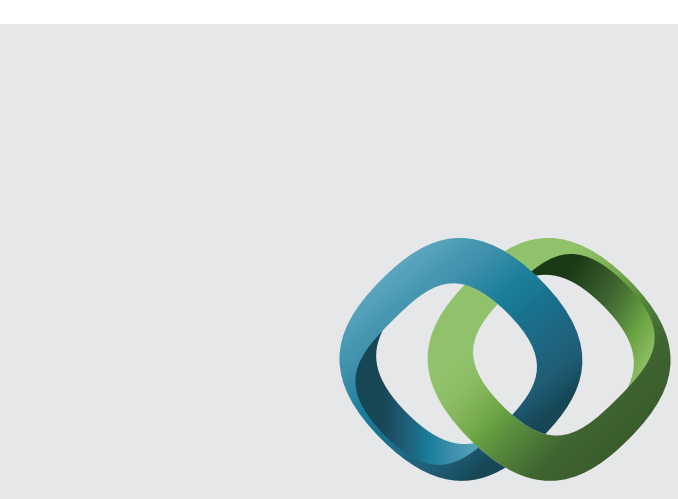

\section{Hindawi}

Submit your manuscripts at

http://www.hindawi.com
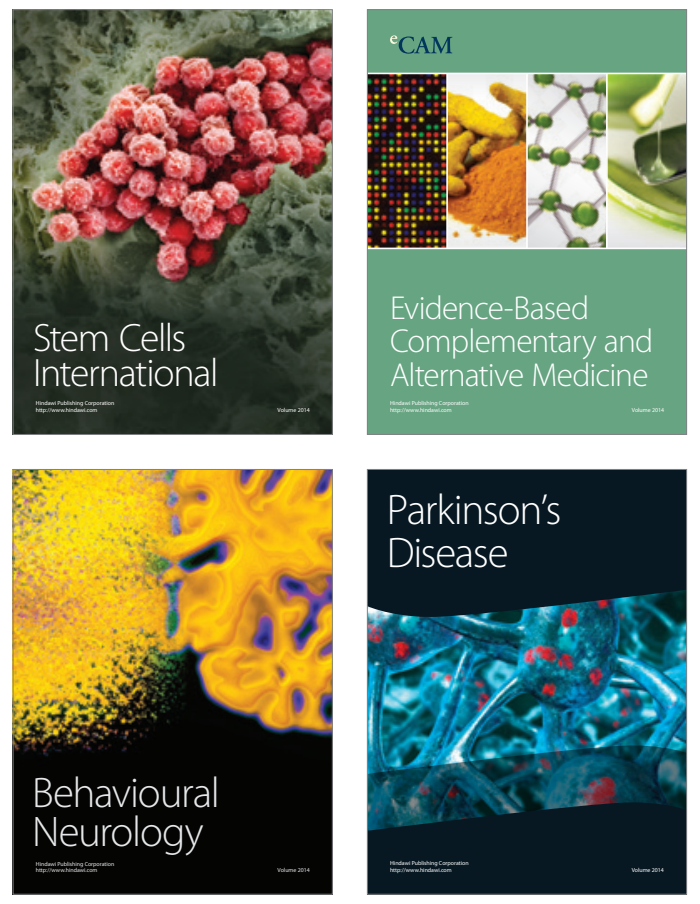
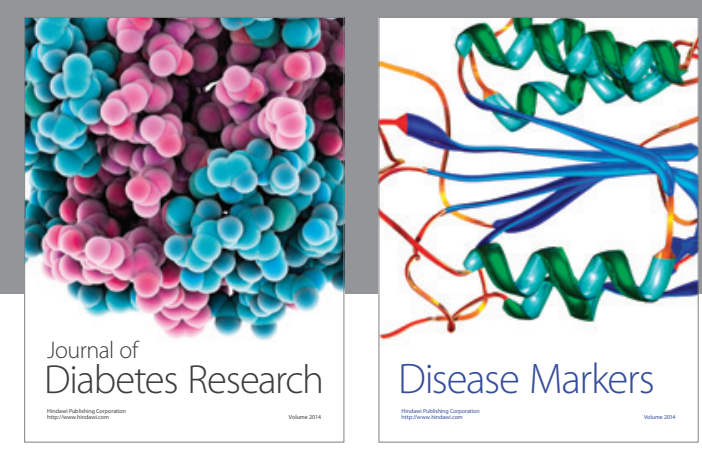

Disease Markers
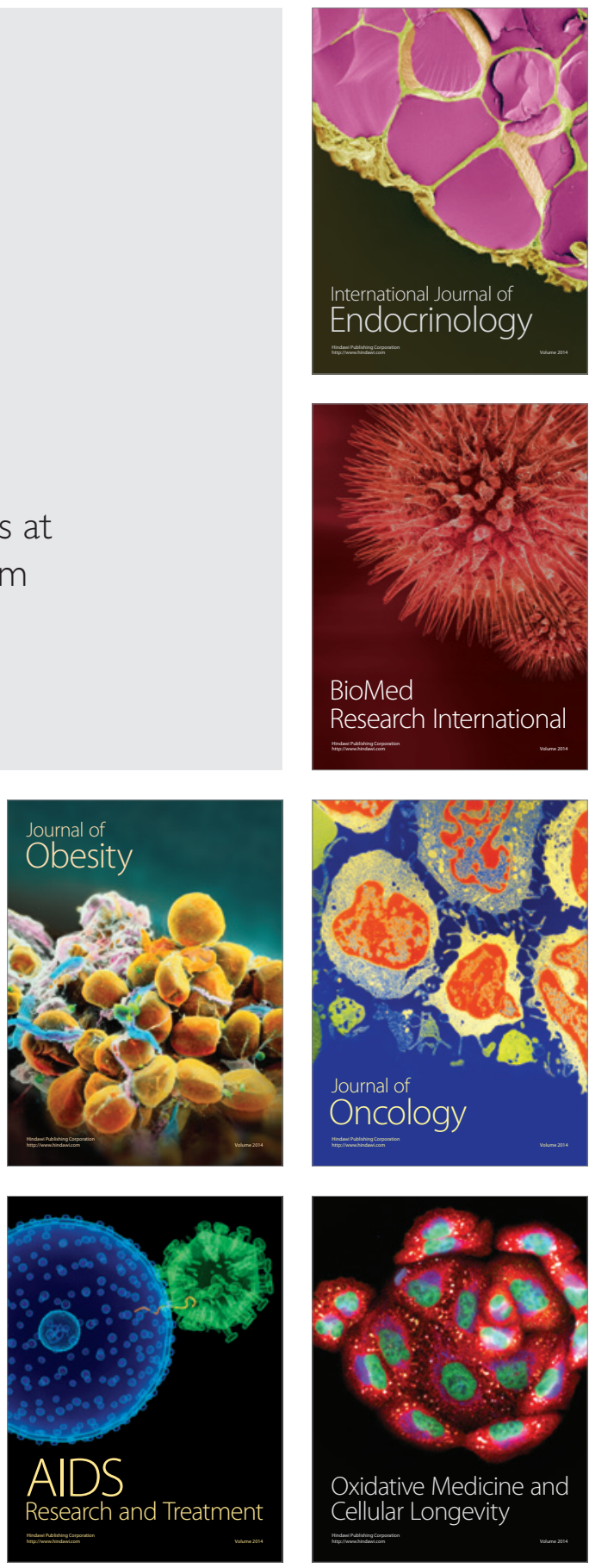